https://journal.uwgm.ac.id/index.php/abdimasmahakam

E-ISSN: 2549-5755

Januari 2020, Vol. 4 No. 01

Received: September 2019

Accepted: Desember 2019

Published: Januari 2020

Article DOI: http://dx.doi.org/ 10.24903/jam.v4i1.809

\title{
Pencegahan Merokok Sejak Dini melalui Penyuluhan Bimbingan dan Konseling
}

\author{
Rosdiana \\ UniversitasWidya Gama Mahakam Samarinda \\ anahanur@gmail.com
}

\begin{abstract}
Abstrak
Berdasarkan Peraturan Pemerintah Republik Indonesia No.109 tahun 2012 tentang, Pengamanan bahan yang mengandung Zat Adiktif berupa produk tembakau/rokok. Asapnya mengandung nikotin dan tar, dengan atau tanpa bahan tambahan (Kemenkes RI, 2012). Menurut hasil survei Direktorat Pengendalian Penyakit Kementerian Kesehatan dan dibantu oleh Dinas Kesehatan Kota Samarinda diketahui sebanyak 24\% siswa SMP dan siswa SMA merokok. Survei ini dilakukan pada delapan sekolah di Kota Samarinda pada tingkat SMP dan SMA dengan melibatkan 320 pelajar. Adapun alasan pelajar merokok dikarenakan dipengaruhi oleh harga yang murah dan iklan rokok yang selalu intens ditayangkan di televisi maupun reklame rokok yang menjamur di bantaran jalan Kota Samarinda (Profil Dinkes Kota Samarinda 2016). kegiatan memberikan pengetahuan, pemahaman mengenai bahan yang terdapat dalam rokok serta bahaya dan resiko bagi perokok dan orang yang berada disekitarnya, memberikan bimbingan dan konseling, agar siswa tidak merokok lagi, dan membangun motivasi agar bisa sukses melalui potensi yang dimiliki. Metode yang digunkan yaitu, penyuluhan kombinasi dengan role play dan FGD, bimbingan dan konseling. Hasil kegiatan melalui evaluasi diakhir dengan cara tanya jawab kepada siswa, menggambarkan siswa yang mengikuti penyuluhan sebanyak 54 orang mengetahui dan memahami bahan yang terdapat pada rokok serta bahaya dan dampak akibat mengkonsumsinya.
\end{abstract}

Kata Kunci: Pencegahan merokok; penyuluhan; bimbingan; dan konseling.

\section{Pendahuluan}

Berdasarkan data World Health Organization (WHO) dalam Kemenkes RI RISKESDAS (2018) menempatkan Indonesia sebagai pasar rokok tertinggi dan jumlah perokok terbesar di dunia setelah China dan India. Prevalensi perokok laki-laki dewasa di Indonesia bahkan yang paling tinggi $(68,8 \%)$ di dunia. Pada tahun 2015 WHO menyebutkan dari hasil survey di Indonesia terhadap 4.313 siswa kelas 7-9 dengan rentang usia 13-15 tahun (laki-laki berjumlah 2029 dan perempuan 2284) pada sekolah yang dipilih, di temukan bahwa terdapat $18.3 \%$ perokok aktif. Sebanyak 30,9\% siswa merupakan mantan perokok (laki-laki dan perempuan). Hasil penelitian tersebut menunjukkan bahwa beberapa remaja usia<13 tahun sudah mulai mencoba merokok. (Kemenkes RI, 2013).

Menurut hasil survei Direktorat Pengendalian Penyakit Kementerian Kesehatan dan dibantu oleh Dinas Kesehatan Kota Samarinda diketahui sebanyak 24\% siswa SMP dan siswa SMA 


\section{(A) ABDIMAS}

https://journal.uwgm.ac.id/index.php/abdimasmahakam

E-ISSN: 2549-5755

Januari 2020, Vol. 4 No. 01

merokok. Survei ini dilakukan pada delapan sekolah di Kota Samarinda pada tingkat SMP dan SMA dengan melibatkan 320 pelajar. Adapun alasan pelajar merokok dikarenakan dipengaruhi oleh harga yang murah dan iklan rokok yang selalu intens ditayangkan di televisi maupun reklame rokok yang menjamur di bantaran jalan Kota Samarinda (Profil Dinkes Kota Samarinda 2016).

Selama ini siswa SMP Negeri 29 Samarinda yang merokok, mengetahui bahaya rokok dar kemasan atau bungkusnya saja, di mana pada kemasan rokok tertulis "merokok dapat menyebabkan kanker, serangan jantung, impotensi dan gangguan kehamilan dan janin".Selain itu gambar yang sangat menyeramkan, dimana secara fakta sulit ditemukan pada perokok di lingkungan sekitarseperti contoh gambar pada kemasan rokok tersebut.sehingga siswa menganggap itu hanya ancaman dan gambar karikatur pada kemasan rokok.

Proses bimbingan dan konseling akan membantu siswa dalam memahami tingkah laku manusia yang baik dan buruk, sebagai referensi dalam memilih dan memilah teman/ sahabat yang baik dan sesuai dengan dirinya. Membantu siswa untuk hidup seimbang dalam aspek jasmani, rohani, emosi dan sosial. Membantu siswa untuk mengembangkan diri sesuai dengan potensi yang dimiliki. Membantu sosialisasi dan sensitifikasi siswa terhadap kebutuhannya dan membantu siswa dalam memperoleh kepuasan diri, dan masih banyak lagi fungsi bimbingan dan konseling lainnya. Diharapkan siswa dapat memutuskan sendiri untuk tidak merokok ataupun merokok baik secara terang-terangan ataupun sembunyi-sembunyi.

\section{Metode}

Metode yang digunakan dalam pelaksanaan kegiatan pengabdian kepada masyarakat di SMP Negeri 29 adalah penyuluhan, bimbingan dan konseling. Adapun mekanisme pelaksanaan kegiatan, sebagai berikut: Penyuluhan dikombinasi dengan roll play dan FGD. Dilakukan di ruang serba guna sekolah SMP Negeri 29 Samarinda. Gambaran pelaksanaan ada tiga sesi, yaitu: Pemaparan materi, Focus group discision (FGD) dan evaluasi. Bimbingan dan konseling dilaksanakan di ruang kelas, adapun kegiatan yang dilakukan merupakan pemberian bantuan, berupa saran, arahan, nasehat dengan cara sedemikian rupa, sehingga pemahaman terhadap kemampuan diri sendiri meningkat dalam memecahkan berbagai masalah agar bisa berhenti merokok. Peserta yang ikut adalah siswa yang terdeteksi merokok pada saat pelaksanaan FGD di acara penyuluhan dan berdasarkan referensi dari guru BK sekolah. (Brown, Luckett, Davidson, \& DiGiacomo, 2017). Dilanjutkan Rapat koordinasi antar konselor, untuk membicarakan dan memutuskan daftar siswa yang ikut program bimbingan dan konseling, serta merumuskan pola bimbingan dan pembinaan selanjutnya.

\section{Hasil dan Pembahasan}

Dalam pelaksanaan kegiatan pengabdian kepada masyarakat di SMP Negeri 29 adalah penyuluhan, bimbingan dan konseling. Adapun mekanisme pelaksanaan kegiatan, sebagai berikut: Penyuluhan dikombinasi dengan roll play dan FGD. Dilakukan di ruang serba guna sekolah SMP Negeri 29 Samarinda dengan jumlah peserta 54 orang. Gambaran pelaksanaan ada tiga sesi, yaitu: Pemaparan materi, dengan isi materi sebagai berikut; pengertian dan jenis-jenis rokok, kandungan rokok, bahaya dan resiko rokok terhadap kesehatan jika masuk ke dalam tubuh manusia. Proses pemaparan dibantu oleh pemutaran video (proses zat kimia 


\section{(A) ABDIMAS}

https://journal.uwgm.ac.id/index.php/abdimasmahakam

E-ISSN: 2549-5755

Januari 2020, Vol. 4 No. 01

yang ada di dalam rokok masuk ke dalam tubuh manusia dengan cara dihisap atau dihirup, hingga merusak organ tubuh manusia dan menimbulkan beberapa penyakit degenerative. Video testimony, beberapa orang yang menceritakan pengalamannya merokok hingga menderita suatu penyakit tertentu).

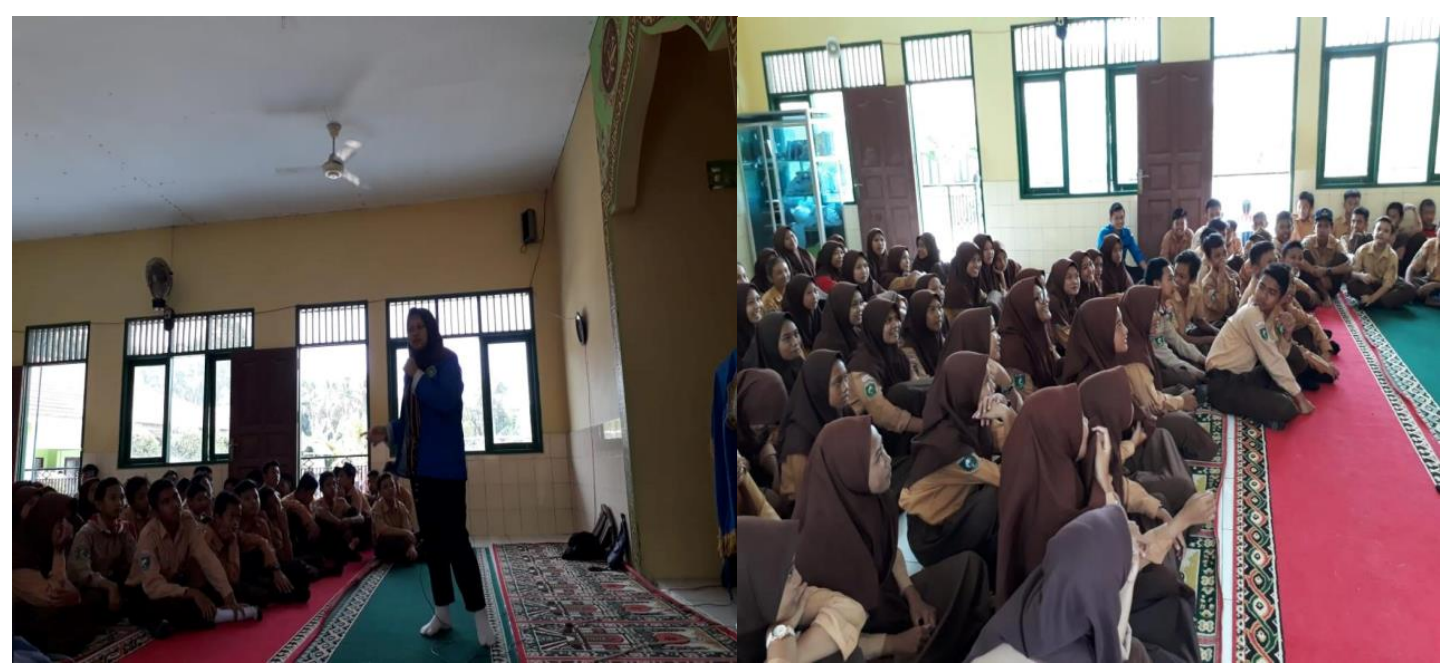

Gambar. 1 Pemaparan Materi

Evaluasi, di akhir pembahasan tiap tema, diadakan evaluasi oleh tim pelaksana. Indikator yang di evaluasi, pengetahuan siswa mengenai materi yang telah disajikan, melalui roll play dengan prosedur pelaksana mengajukan satu pertanyaan kepada salah satu peserta, pertanyaannya "sebutkan salah satu kandungan rokok", apabila berhasil dijawab, peserta tersebut mengajukan pertanyaan ke peserta lain yang ada hubungannya dengan materi yang baru saja di sampaikan oleh penyaji, dan seterusnya. Apabila ada peserta yang tidak bisa menjawab, maka akan di berikan selempang yang bertuliskan "mohon bantuannya". Diakhir sesi kedua, peserta yang menggunakan selempang dan tampil ke depan ada dua orang.

Sebagai sangsinya untuk menampilkan potensi yang dimiliki, seperti bernyanyi, standup komedi, baca puisi dan potensi lainnya. Sistem/aturan yang digunakan dalam roll paly tersebut, terlebih dahulu disosialisasikan kepada peserta sebelum sesi pertama dilakukan. Berdasarkan hasil kegiatan evaluasi yang dilakukan kepada peserta penyuluhan, ada 4 peserta yang tidak sempat menjawab secara spontan karena kehabisan waktu dari 32 yang dievaluasi secara acak. Kegiatan penyuluhan menambah pengetahuan dan pemahaman siswa terhadap apa saja kandungan yang terdapat dalam rokok serta bahaya dan resikonya jika dikonsumsi.

Focus group discision (FGD), pelaksana membentuk beberapa kelompok, kemudian menentukan tema/kasus, antara lain; alasan seseorang harus berhenti merokok, cara berhenti merokok, upaya pencegahan dan tema/kasus menarik lainnya. untuk didiskusikan bersama. Tujuannya adalah mengidentifikasi, memastikan peserta yang merokok. Bersama-sama dengan guru BK menentukan daftar siswa yang akan mengikuti bimbingan dan konseling.

Bimbingan dan konseling dilaksanakan di ruang kelas. Peserta yang ikut adalah siswa yang terdeteksi merokok pada saat pelaksanaan FGD di acara penyuluhan dan berdasarkan referensi dari guru BK sekolah sebanyak 15 orang. Bimbingan dan konseling merupakan pemberian bantuan, berupa saran, arahan, nasehat dengan cara sedemikian rupa, sehingga 
https://journal.uwgm.ac.id/index.php/abdimasmahakam

E-ISSN: 2549-5755

Januari 2020, Vol. 4 No. 01

pemahaman terhadap kemampuan diri sendiri meningkat dalam memecahkan berbagai masalah agar bisa berhenti merokok.

Tahapan pelaksanaan, yaitu; 1 . Berkumpul di satu ruangan, untuk mendengarkan pengarahan dan penjelasan sistematika bimbingan dan konseling, mengisi biodata pada formulir yang telah disiapkan oleh pelaksana PKM. 2. System bimbingan dan konseling dengan one by one, dan ditangani oleh tiga orang konselor. Sambil menunggu giliran untuk masuk ke ruangan konselor, peserta bisa mengisi waktu dengan bersantai sambil nonton film yang bisa membangkitkan semangat juang meraih cita-cita, seperti cerita dalam film, mimpih ananda raih semesta, sekolah rimba, di timur matahari.

Proses bimbingan dan konseling, sesuai dengan fungsinya, maka konselor melakukan proses Tanya-jawab untuk mengintervensi siswa dengan tujuan untuk meningkatkan pemahaman tentang dirinya sendiri, sadar akan potensi yang dimiliki, memaksimalkan kebebasan, mengefektifkan diri dan bijaksana dalam mengambil keputusan. Rapat koordinasi antar konselor, untuk membicarakan dan memutuskan daftar siswa yang memiliki karakter, hobby serta potensi yang sama dalam satu kelompok. Tujuannya agar lebih mudah dan terarah dalam prosese bimbingan dan konseling lanjutan. Pola bimbingan dan pembinaan berdasarkan keinginan siswa serta potensi yang dimilikinya.

\section{Simpulan dan rekomendasi}

Berdasarkan hasil kegiatan evaluasi yang dilakukan kepada peserta penyuluhan, ada 4 peserta yang tidak sempat menjawab secara spontan karena kehabisan waktu dari 32 yang dievaluasi secara acak. Kegiatan penyuluhan menambah pengetahuan dan pemahaman siswa terhadap apa saja kandungan yang terdapat dalam rokok serta bahaya dan resikonya jika dikonsumsi. Diharapkan program bimbingan dan konseling tetap berjalan di sekolah SMPN 29 Samarinda, guru BK lebih aktif dalam menjalankan program khususnya pengembangan potensi anak didik melalui bidang olahraga, seni dan akademik. 


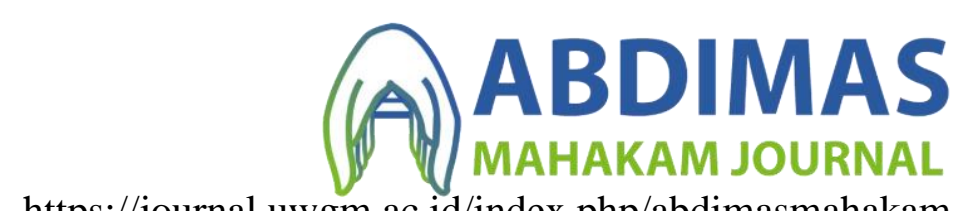

https://journal.uwgm.ac.id/index.php/abdimasmahakam

E-ISSN: 2549-5755

Januari 2020, Vol. 4 No. 01

\section{Daftar Pustaka}

Kemenkes RI. 2018. Riset Kesehatan Dasar RISKESDAS. Jakarta: Badan Penelitian dan Pengembangan Kesehatan.

Kemenkes RI. 2013. Riset Kesehatan Dasar RISKESDAS. Jakarta: Badan Penelitian dan Pengembangan Kesehatan.

Profil Dinas Kesehatan Kota Samarinda. 2016. Angka Perokok Pada Usia 5-15 Tahun. Samarinda.

Kemenkes RI. 2013. “Anak Remaja Rentan Menjadi Perokok Pemula”. URL:http//www.depkes.go.id.

Notoatmodjo. "Promosi Kesehatan”. Rineka cipta 2012

Corey, Gerald. 2013. "Teori dan Prektik Konseling \& Psikoterapi”. Terjemahan E. Koswara. Rafikaaditama Bandung.

Brown, N., Luckett, T., Davidson, P. M., \& DiGiacomo, M. (2017, August 1). Family-

Focussed Interventions to Reduce Harm from Smoking in Primary School-Aged

Children: A Systematic Review of Evaluative Studies. Preventive Medicine, Vol. 101, pp. 117-125. https://doi.org/10.1016/j.ypmed.2017.06.011 